\%

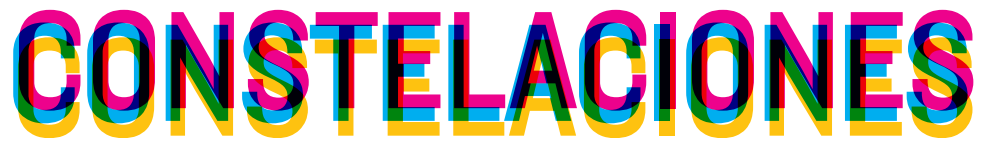

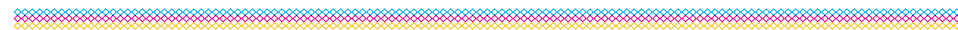


CONSTELACIONES n², mayo 2014

Revista de Arquitectura de la Universidad CEU San Pablo

Architecture Magazine of CEU San Pablo University

Periodicidad anual

Annual periodicity

COMITÉ DE REDACCIÓN EDITORIAL COMMITTEE

\section{Director Director}

Juan García Millán

Jefa de Redacción Editor in Chief

Covadonga Lorenzo Cueva

Secretario de Redacción Editorial Clerk

Rodrigo Núñez Carrasco

Maquetación y producción Design and production

María Fernández Hernández

Vocales Board Members

Fernando del Ama Gonzalo. Escuela Politécnica Superior, Universidad CEU San Pablo, Madrid

Pablo Campos Calvo-Sotelo. Escuela Politécnica Superior, Universidad CEU San Pablo, Madrid

Alfonso Díaz Segura Escuela Superior de Enseñanzas Técnicas, Universidad CEU Cardenal Herrera, Valencia

Mayka García Hípola. Escuela Politécnica Superior, Universidad CEU San Pablo, Madrid

Sonia Izquierdo Esteban. Escuela Politécnica Superior, Universidad CEU San Pablo, Madrid

Javier Sáenz Guerra. Escuela Politécnica Superior, Universidad CEU San Pablo, Madrid

\section{CONSEJO EDITORIAL EDITORIAL BOARD}

Beatriz Colomina. School of Architecture, Princeton University, New Jersey

Carmen Díez Medina. Escuela de Ingeniería y Arquitectura, Universidad de Zaragoza

María Antonia Frías Sargadoy. Escuela Técnica Superior de Arquitectura, Universidad de Navarra

Ángel González García. Facultad de Geografía e Historia, Universidad Complutense de Madrid

Juan Miguel Hernández Léon. Escuela Técnica Superior de Arquitectura, Universidad Politécnica de Madrid

Juan José Lahuerta Alsina. Escuela Técnica Superior de Arquitectura, Universidad Politécnica de Cataluña, Barcelona

Eduardo Leira Sánchez. Ex director del Plan General de Ordenación Urbana, Madrid

Joaquín Medina Wamburg. Facultad de Aquitectura Diseño y Urbanismo, Universidad de Buenos Aires

Zaida Muxí Martínez. Escuela Técnica Superior de Arquitectura, Universidad Politécnica de Cataluña, Barcelona

José Joaquín Parra Bañón. Escuela Técnica Superior de Arquitectura, Universidad de Sevilla

Víctor Pérez Escolano. Escuela Técnica Superior de Arquitectura, Universidad de Sevilla

Fernando Pérez Oyarzún. Escuela de Arquitectura y Diseño, Pontificia Universidad Católica, Santiago de Chile Judith Sheine. School of Architecture and Allied Arts, University of Oregon, Portland

Andrés Walliser Martínez. Global Design, New York University, Nueva York

\section{ISSN 2340-177X}

Depósito legal M-13872-2013

(c) de los textos, sus autores

(c) de las imágenes autorizadas

(c) Revista Constelaciones

๑) Escuela Politécnica Superior, Universidad CEU San Pablo

Universidad CEU San Pablo

Escuela Politécnica Superior

Urbanización Montepríncipe, $s / n$

Boadilla del Monte, 28668. Madrid (España)

constelaciones@eps.ceu.es

www.uspceu.es

Edición Edition

Fundación Universitaria San Pablo CEU

Madrid, España

Impresión Printing

VA Impresores

Impreso en España Printed in Spain

Distribución Distribution

CEU Ediciones

Los textos que componen Constelaciones se obtienen mediante convocatoria pública. Para que los trabajos recibidos entren en el proceso de selección de los artículos a publicar deben ser trabajos originales no publicados anteriormene, con una extensión recomendada de 3.000 palabras, título, resumen (un máximo de 150 palabras) y palabras clave (un mínimo de cuatro palabras), en español y en inglés. Tras haber cumplido estos requisitos (y los correspondientes incluidos en las normas editoriales de la revista, disponibles para consulta en formato digital desde el comienzo de la convocatoria), tiene lugar un proceso de revisión y evaluación de los artículos previa aceptación de los mismos para su publicación. Para acometer dicho proceso, y con el fin de asegurar la calidad de los contenidos, la Revista Constelaciones recurre a evaluadores externos a la institución editora y anónimos (cada artículo es evaluado por dos de ellos) encargados de someter a crítica los mismos. Todos los artículos de investigación publicados en esta revista han pasado por dicho proceso. La recepción de artículos se extendió hasta el 30 de Septiembre de 2013. Texts included in Constelaciones are obtained by public announcement. Only original papers that have not been previously published will be included in the process of selection of articles. They should not exceed 3.000 words and should include a title, an abstract (no more than 150 words) and keywords (a minimum of four words), in Spanish and English. After having fulfilled these requirements (and those included in magazine editorial standards, available for consultation from the beginning of the Call for Papers), occurs a process of review and evaluation of articles upon acceptance of them for publication. To undertake this process, and in order to ensure the quality of the contents, Constelaciones turns to external and anonymous evaluators to the institution (each article is evaluated by two of them) responsible for the critic. All the articles published in this journal have undergone this process. The deadline for reception was extended until September 30, 2013.

Todos los derechos reservados. Esta publicación no puede ser reproducida, ni en todo ni en parte, ni registrada, ni transmitida, ni almacenada en ningúna forma ni por ningún medio, sin la autorización previa y por escrito del equipo editorial. En este número se han utilizado algunas imágenes de las que no se ha podido identificar al propietario de los derechos. En estos casos hemos entendido que las imágenes son de libre uso. En caso de identificar alguna de estas imágenes como propia, por favor, póngase en contacto con la redacción de Constelaciones. Los criterios expuestos en los diversos artículos de la revista, son responsabilidad exclusiva de sus autores, y no reflejan necesariamente los que pueda tener el equipo editoral. El equipo editorial de la revista no se responsabiliza de devolver la información enviada a la redacción a no ser que se le solicite expresamente. All rights reserved. This publication cannot be reproduced, in whole or in part, nor registered, transmitted or stored in any form or by any means, without the written permission of the Editorial team, In this issue some images were used without knowing the owner of the rights. In these cases, we have understood that the images are free of use. In case you identify written permission of the Editorial team, In this issue some images were used without knowing the owner of the rights. In these cases, we have understood that the images are free of use. In case you identify
any of these images as your own, please, contact with the Editorial staff of Constelaciones. The opinions expressed in this issues's articles are entirely the responsibility of their authors and are not necessarily shared by the editors of this journal. The publisher don't take responsibility for returning submitted material which is not expressly requested. 


$$
11
$$




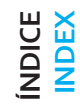

$\stackrel{n}{\sim}$

ร

5

$\curvearrowright$

๙ิ

$\stackrel{n}{=}$

$\bar{m}$
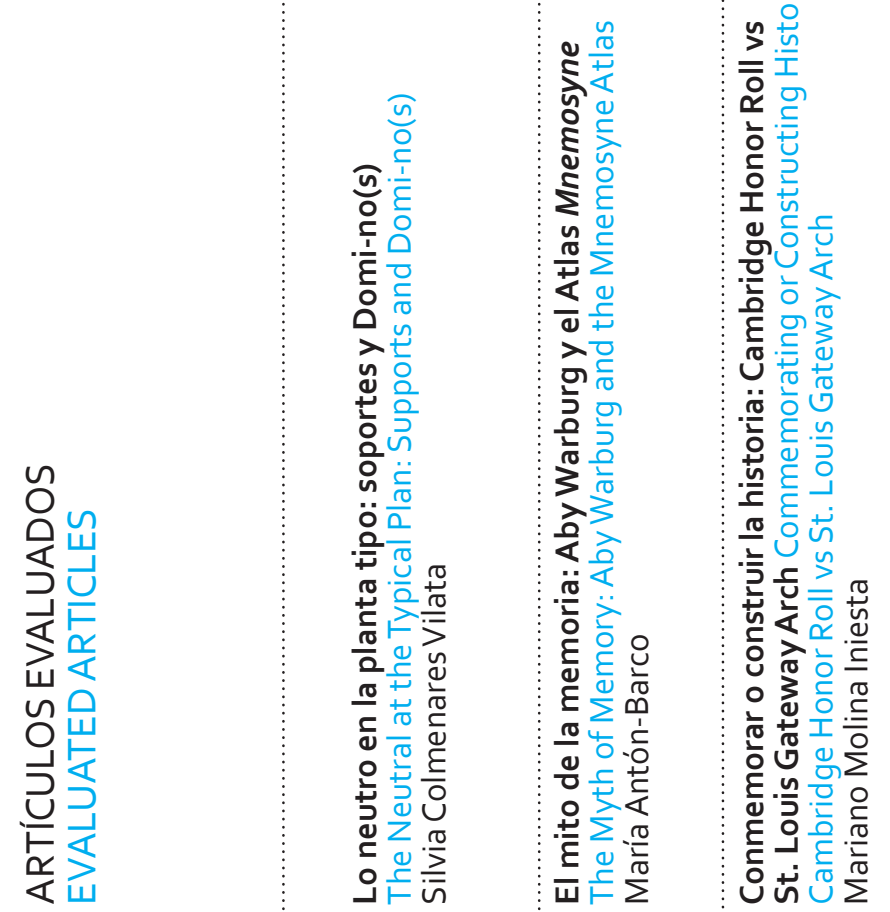

旁 을

‥

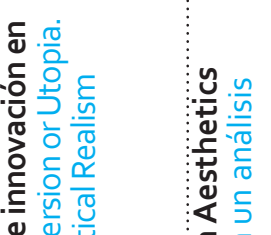

앙

胥苞

$\bar{\Psi}$

宛

일

능홍

区告

음 흠

응 흥

\%

든

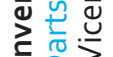

ข

음

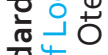

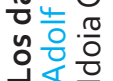

a व

은

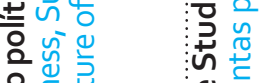

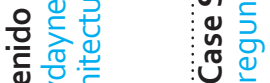

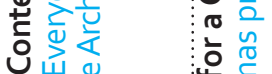

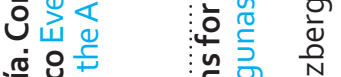

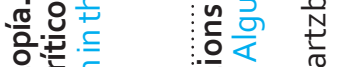

गे

गे० गे ये ज

:

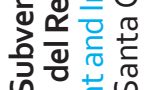

है

ज०

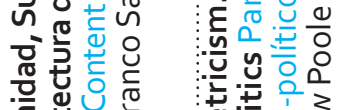

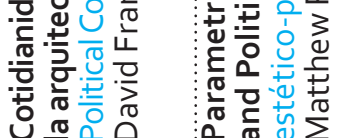

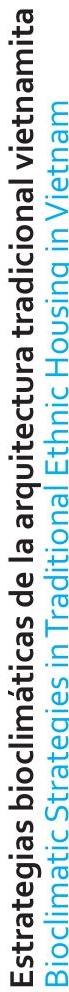

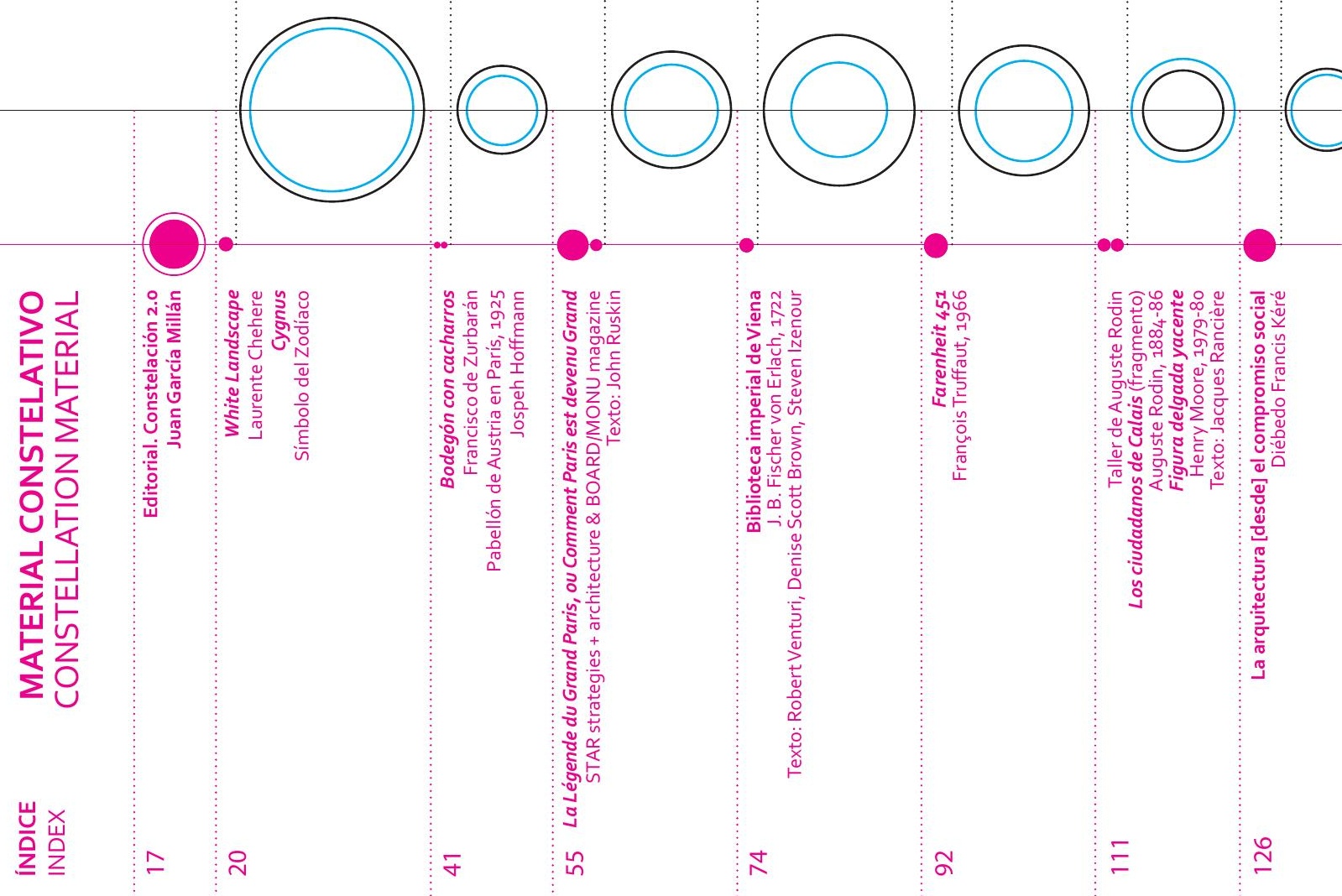

苍

० 


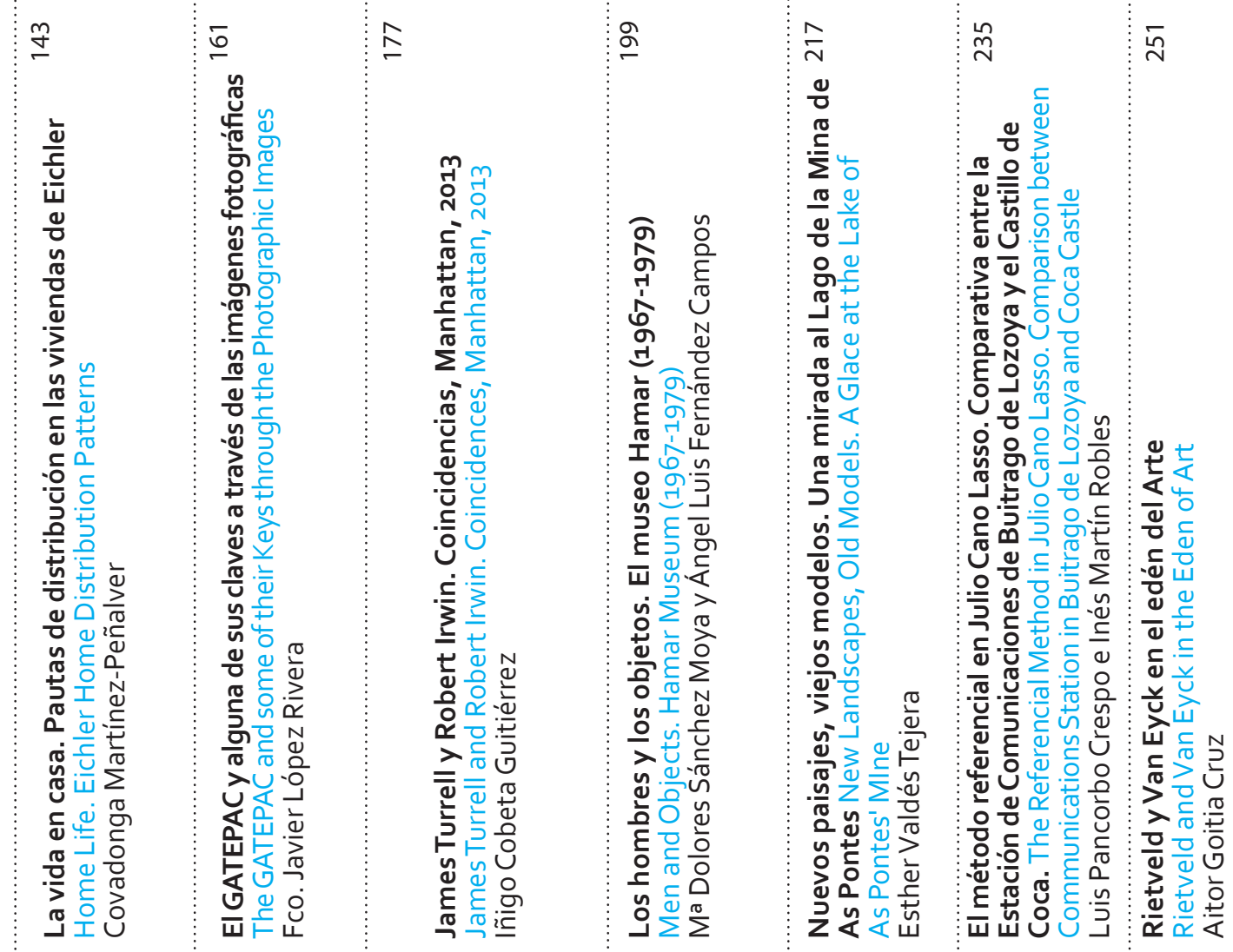
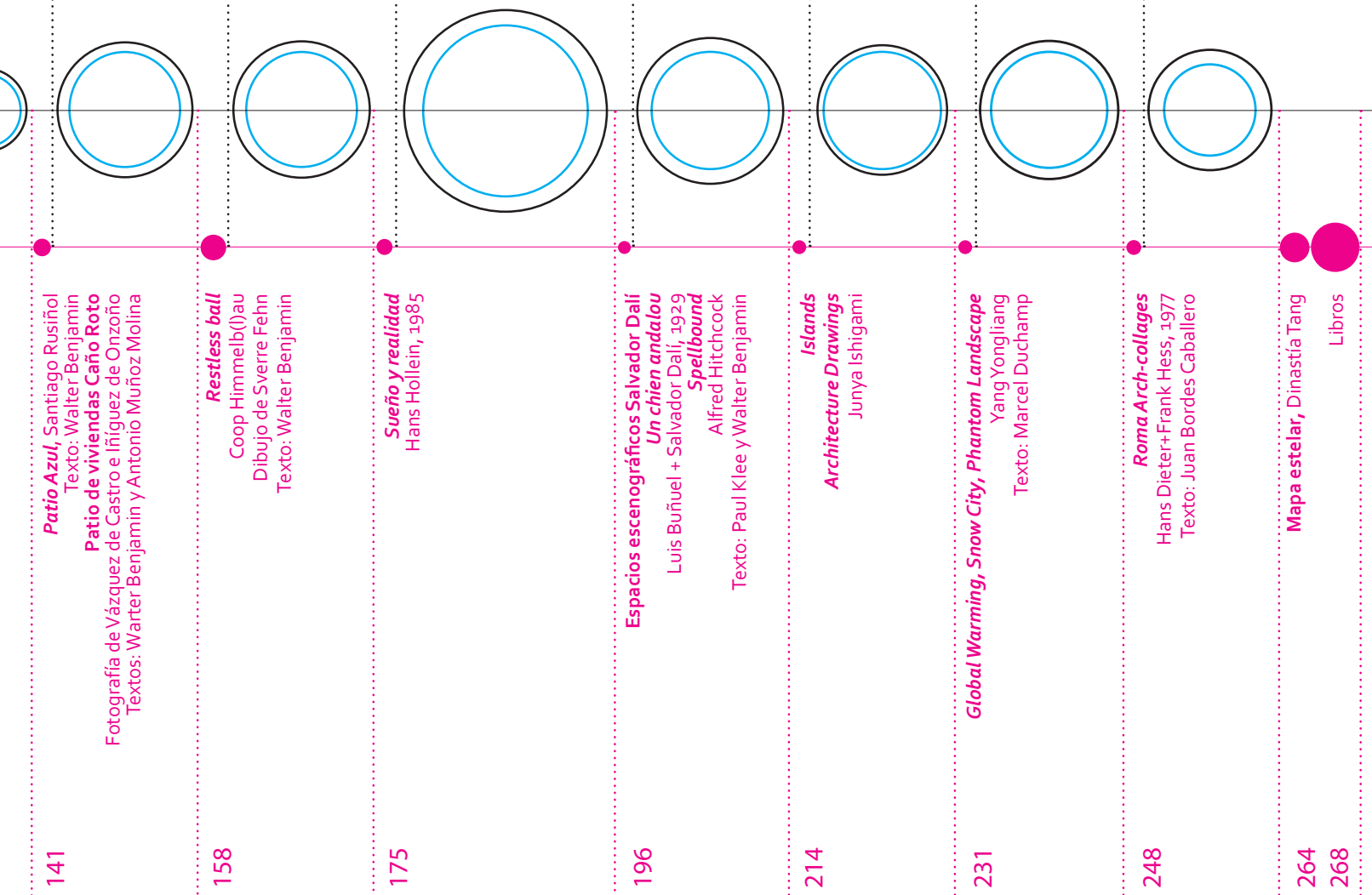



\title{
Conmemorar o construir la historia: Cambridge Honor Roll vs St. Louis Gateway Arch Commemorating or Constructing History: Cambridge Honor Roll vs St. Louis Gateway Arch
}

\author{
Mariano Molina Iniesta \\ Escuela Politécnica Superior, Universidad CEU San Pablo, Madrid \\ Traducción Translation Hayden Salter \& Mariano Molina Iniesta
}

Palabras clave Keywords

Monumento, posguerra, Estados Unidos, Cambridge Honor Roll, Gateway Arch

Memorial, postwar, United States, Cambridge Honor Roll, Gateway Arch

\section{Resumen}

El artículo vincula la supremacía del living memorial en Estados Unidos, como fórmula conmemorativa de la Segunda Guerra Mundial, con la mayor conciencia social acerca de la naturaleza real de la guerra. De esta manera se puede entender el destino del Cambridge Honor Roll, que a pesar de su modesto presupuesto y la aplicación de la tecnología y el lenguaje moderno, fue rechazado por su falta de utilidad práctica. Paradójica y contemporáneamente, Estados Unidos construyó el mayor monumento sin función de su historia en la ciudad de St. Louis, esta vez para conmemorar dos eventos considerados fundamentales para la conformación del país.

\section{Abstract}

This text establishes the connection between the supremacy of the 'living memorial' in the United States, as a way to commemorate the Second World War, with a heightened social awareness about the true nature of war. In this light, the fate of the Cambridge Honor Roll is explained. Despite its modest budget and the use of modern technology and language, the proposal was rejected for its lack of practical utility. Paradoxically, in the city of St. Louis, the United States built at this same time the largest non-utilitarian monument in their history to commemorate two events considered essential in the shaping of the country. 
Hacia el final de la Segunda Guerra Mundial se asistió a la popularización en Estados Unidos de una nueva forma de conmemoración denominada living memorial, que esencialmente se caracterizaba por asociar el recuerdo de los caídos con actividades de tipo cultural, social y deportivo que fortalecieran las ideas de comunidad y democracia, aquéllas por las que precisamente habían dado su vida tantos soldados.

Este nuevo modelo venía a poner en cuestión muchas de las cualidades inherentes a los monumentos tradicionales levantados para conmemorar las guerras inmediatamente anteriores. Al mismo tiempo, allanaba el terreno para que los arquitectos funcionalistas pudieran adentrarse en el campo de la arquitectura conmemorativa, y explica el surgimiento en la década de 1940 de un intenso debate sobre la posibilidad de una monumentalidad moderna, cuyos resultados más destacables en términos teóricos son probablemente los manifiestos Nine points on Monumentality, redactado por José Luis Sert, Sigfried Giedion y Fernand Léger en 1943, y Monumentality, escrito por Louis Kahn en 1944. Además de la incorporación de los usos mencionados antes, ambos textos incidían en la dimensión urbana del monumento moderno, mediante la incorporación de un espacio abierto para la reunión espontánea de los ciudadanos.

En realidad, ese cuestionamiento de la monumentalidad tradicional ya se había iniciado, aunque con menor fortuna, inmediatamente después de la Primera Guerra Mundial. Diversos artículos defendían como alternativa las casas comunitarias construidas para el recreo de los soldados en las inmediaciones de los campos de entrenamiento que, abiertas tras la guerra a los civiles, fomentarían la interacción entre ambos colectivos y reafirmarían entre la ciudadanía los ideales por los que se combatió en la Gran Guerra. (Fig. 1) "Además de proveer de un espacio para grandes bailes y encuentros, para películas que la comunidad al completo vendrá a ver, para diversión organizada, y para actividades educativas y de asistencia social, la Casa Comunitaria albergará un agradable centro de las artes, que, en la nueva democracia, debe ser accesible para todos, en lugar de cómo hasta ahora, reservada a unos pocos favorecidos". (1)

Towards the end of the Second World War, the United States witnessed the popularization of a new way of commemoration called 'living memorial', essentially characterized by associating the memory of the fallen with cultural, social and sporting activities which would strengthen the ideas of community and democracy, precisely those for which so many soldiers had given their lives.

This new model came to question many of the inherent qualities of traditional monuments erected to commemorate previous wars. At the same time, it paved the way for functionalist architects to enter the field of commemorative architecture, and explains the emergence in the 1940s of an intense debate about the possibility of a modern monumentality, whose most remarkable theoretical results are probably the manifestoes Nine points on Monumentality, drafted by José Luis Sert, Sigfried Giedion and Fernand Léger in 1943, and Monumentality, written by Louis Kahn in 1944. In addition to incorporating the functions mentioned above, both texts emphasized the urban dimension of the modern monument, by means of including an open space for the spontaneous meeting of citizens.

Actually, this questioning of traditional monumentality had already begun, although less successfully, immediately after the First World War. Various articles proposed the community houses built for the recreation of the soldiers in the vicinity 
A pesar de todo, a favor de los monumentos tradicionales podía alegarse que la incorporación de funciones prácticas podría socavar su objetivo fundamental, el recuerdo. El número de diciembre de 1926 de la revista Architectural Forum se dedicaba monográficamente a analizar la cuestión, y la mayoría de sus artículos advertían de ese riesgo. Así, se describía por ejemplo la construcción de una escuela o un ayuntamiento conmemorativos que al cabo de poco tiempo habían perdido esa cualidad ante la ausencia de una clara expresión: "En términos generales, ningún monumento, si pretende ser un auténtico monumento, puede tener una utilidad práctica; o para decirlo de otro modo, ninguna estructura puede servir a dos propósitos. O bien es un monumento de una hazaña o sacrificio o de algún gran hombre, o es simplemente una escuela o un ayuntamiento". (2)

El debate se fue decantando progresivamente a favor de los defensores del living memorial, que durante la Segunda Guerra Mundial ya eran una mayoría aplastante, no sólo en la prensa especializada, sino también en muchas

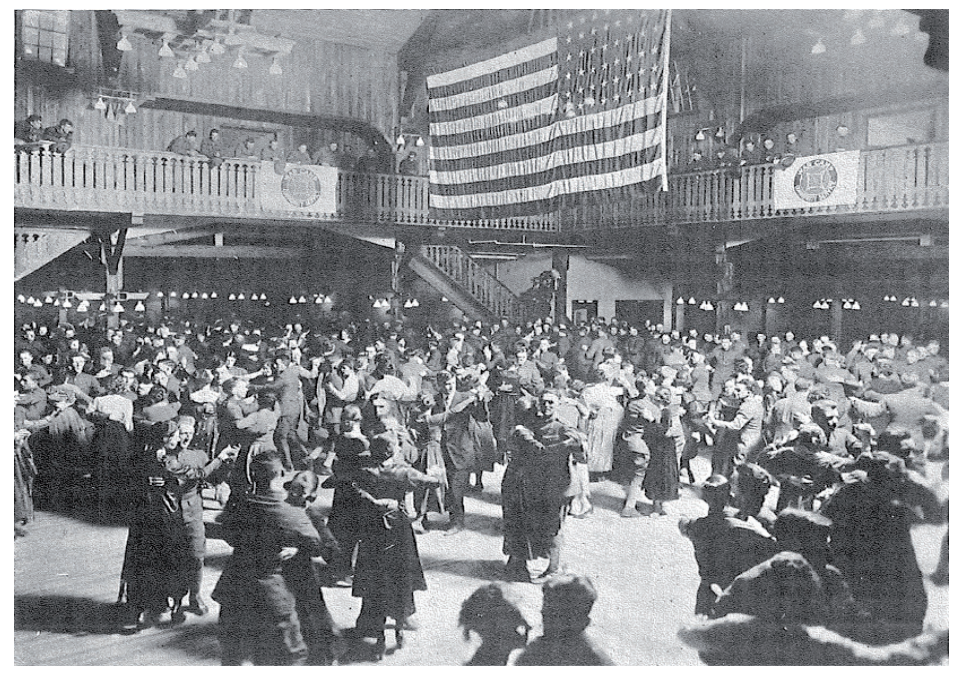

Fig. 1. Baile en la casa comunitaria de Battle Creek, Michigan.

of the training camps as an alternative, which, open to civilians after the war, would promote the interaction between the two groups and reaffirm the ideals for which they fought the Great War. (Fig. 1) "[...] in addition to furnishing a place for the big dances and 'get-togethers', for movies to which the whole community will come, for organized recreation, and for educational and welfare activities, the Community House will furnish a friendly center for the arts, which, in the new democracy, must be made accessible to all, instead of as heretofore, reserved for the favored few". (1)

Nevertheless, in favor of traditional monuments, it could be argued that the incorporation of practical functions would undermine its fundamental purpose, remembering. The December 1926 issue of the Architectural Forum magazine was uniquely devoted to this subject, and most of its articles warned of this risk. Thus, for example, it was described the construction of a memorial school or town hall that shortly after had lost that quality in the absence of a clear expression: "Generally speaking, no memorial, if it is to be a real memorial, can serve any useful purpose; or to put it in another way, no structure can serve two purposes. It is either a memorial of some great act or sacrifice or of some great man, or else it is merely a school or a town hall". (2)

The discussion gradually decanted for advocates of the 'living memorial' who, during the Second World War, were already an overwhelming majority, not only in the press, but also in numerous civil and government organizations. 


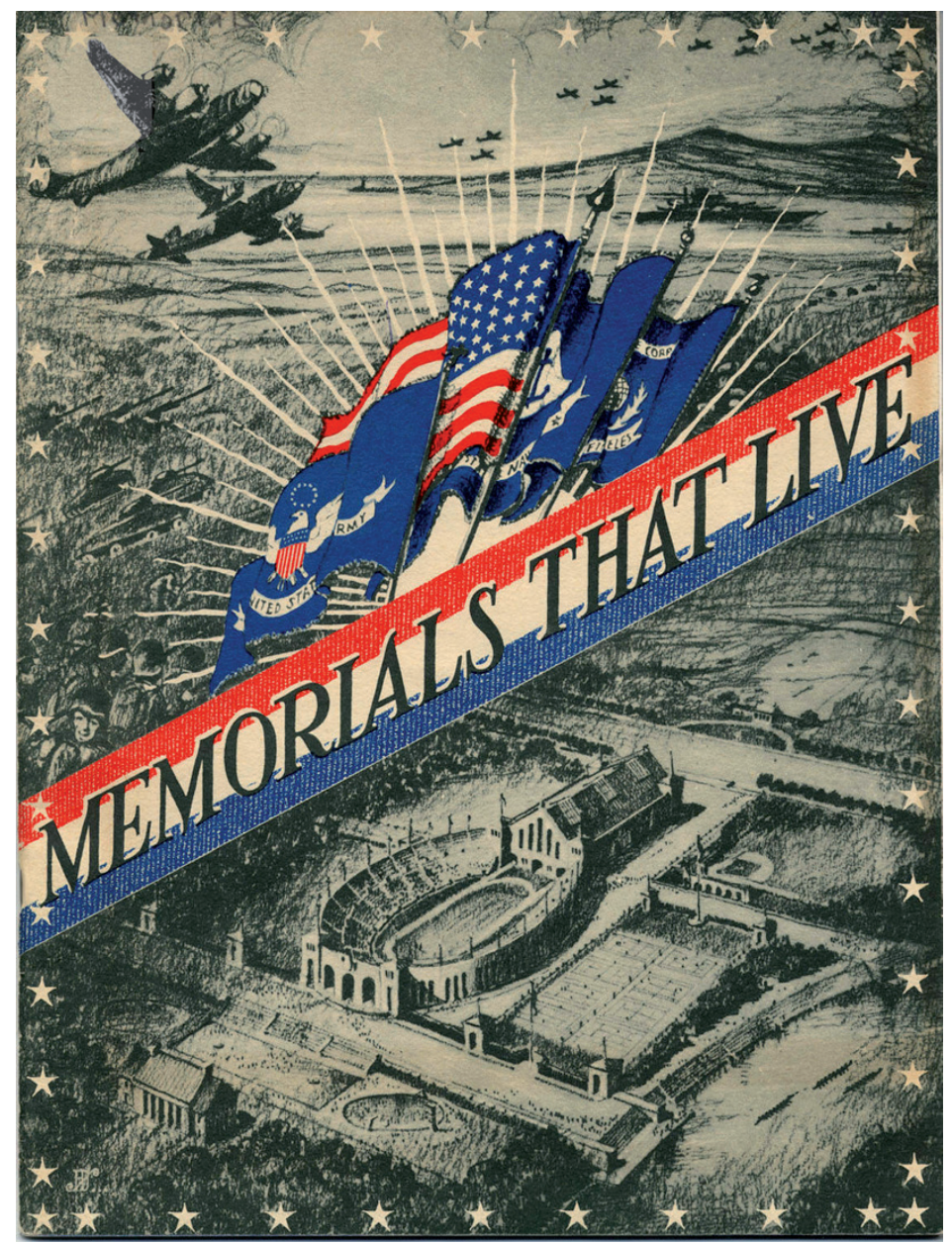

Fig. 2. Portada de Memorials that Live, publicado por la American Commission for Living War Memorials en 1944.

Among the latter, the American Commission for Living War Memorials ) published in 1944 a widely distributed pamphlet entitled Memorials That Live, (Fig. 2) that identified commemorative practice almost exclusively with physical activity, which in turn related to the physical fitness of the fighting troops. At the same time, the editor of the Pencil Points magazine emphatically proclaimed 'Memorials? Yes - But No Monuments' in an editorial, to assert later that "if Life, Liberty, and the Pursuit of Happiness are the ideals at stake in this war, let our appreciation of the fact be evident in the things we create to celebrate its winning. Let there be memorial parks and playgrounds and schools and community buildings. Let gardens, groves and forests be planted for the delight and benefit of the people. Let memorial scholarships be founded to give opportunity to the worthy to pursue studies directed in the interests of the general welfare. Let even memorial plans be made for neighborhoods, for communities, and for whole cities - to affect beneficently the lives of all who may live therein. Let whatever we do have a truly social purpose and a practical social result. But let us not again clutter up our villages, towns and cities with the sort of mediocre or even tawdry 'monumental' monstrosities that have been left in the wake of all our earlier wars. The Nazis would, if they prevailed, build plenty of monuments. Their thinking runs in such vainglorious channels. Since we, however, are going to win, let us build instead a better world". (3) 
organizaciones civiles y gubernamentales. Entre estas últimas, la American Commission for Living War Memorials publicó en 1944 un folleto titulado Memorials that Live, (Fig. 2) ampliamente difundido, en el que la práctica conmemorativa se identificaba casi estrictamente con la actividad física, que a su vez se ligaba con la aptitud física de las tropas combatientes. En esa misma época, el editor de la revista Pencil Points proclamaba enfáticamente en un editorial "Memorials? Yes - But No Monuments", para afirmar a continuación que "si la vida, la libertad, y la búsqueda de la felicidad son los ideales en juego en esta guerra, hagamos que la apreciación de este hecho sea evidente en las cosas que creamos para celebrar su consecución. Háganse parques conmemorativos y espacios de juego y escuelas y edificios comunitarios. Plántense jardines y huertos y bosques para el disfrute y el beneficio del pueblo. Concédanse becas conmemorativas para dar la oportunidad a las personas valiosas de seguir estudios en interés del bienestar común. Háganse incluso planes conmemorativos para vecindarios, comunidades y ciudades enteras para beneficiar las vidas de todos los que las habiten. Que todo lo que hagamos tenga un auténtico propósito social y un resultado social práctico.

No abarrotemos de nuevo nuestros pueblos y ciudades con el tipo de monstruosidades 'monumentales' mediocres e incluso de mal gusto que han dejado todas nuestras guerras anteriores. Los nazis, si vencieran, construirían monumentos en abundancia. Su pensamiento circula por esos canales de vanagloria. Sin embargo, puesto que vamos a ganar nosotros, construyamos en cambio un mundo mejor". (3)

El texto, como otros de su época, establece claramente la distinción entre el término 'monumento', que asocia a las estructuras exclusivamente conmemorativas (y podemos adivinar que con una composición y lenguaje clásicos y una tendencia a la pesantez y la gran escala), y la palabra 'memorial' (para la que no disponemos de una equivalencia en castellano), que asocia a esta nueva forma de compatibilizar el recuerdo y el uso (abriendo la puerta, supondremos, a la incorporación del lenguaje moderno). De hecho, muchos arquitectos modernos aprovecharon las oportunidades ofrecidas por el living memorial para empezar a ocuparse de otros programas que

The text, like others at the time, makes clear the distinction between the term 'monument', exclusively identified with commemorative structures (designed in a classical composition and language and with a tendency to heaviness and large scale, we can guess), and the word 'memorial' (for which there is not a translation in Spanish), which became associated with this new way of reconciling memory and function (opening the door, it can be assumed, to the incorporation of the modern language). In fact, many modern architects took advantage of the opportunities offered by the 'living memorial' to begin dealing with other programs which until then had been only marginally addressed by the Modern Movement. For some of them, certain functions alone conferred the building a monumental character: "An aeroplane hangar, though it is enormous, is not monumental. [...] The judicial chamber of the Supreme Court may be smaller but it houses a symbol of democracy and is monumental by function". (4)

But what many others intended was to achieve, through modern language, an architectural expression of the commemorative function of the monument, which did not need its traditional qualities (stillness, symmetry, mass, large scale) but precisely their opposite (dynamism, asymmetry, lightness), more attuned with the modernist principles. Among them, already Philip Johnson warned that function itself would not give the solution to the problem, and that modern architects 
hasta entonces sólo habían sido marginalmente tratados por el Movimiento Moderno. Para algunos de ellos, determinadas funciones, por sí solas, ya conferían al edificio un carácter monumental: "Un hangar de aeroplanos, a pesar de ser enorme, no es monumental [...] La cámara judicial de la Corte Suprema puede ser más pequeña, pero alberga un símbolo de la democracia y es monumental debido a su función". (4)

Pero muchos otros lo que pretendían realmente era alcanzar mediante el lenguaje moderno una expresión arquitectónica de la función conmemorativa del monumento, que no necesitara de las cualidades tradicionales de éste (estatismo, simetría, masa, gran escala) sino precisamente de sus opuestas (dinamismo, asimetría, ligereza), más acordes a los cánones del Movimiento Moderno. Entre ellos, Philip Johnson ya se encargó de advertir que la función por sí sola no daría la solución al problema, y que el arquitecto moderno tendría necesariamente que enriquecer su vocabulario formal para enfrentarse a estas nuevas situaciones: "Llamar conmemorativo a un puente no lo convierte en tal. Sólo la parte de una estructura útil que se separa para una placa dedicatoria, fuente, terraza o algo así puede decirse que tenga la función de recordar. Y esta parte se convierte en un monumento 'sin uso'. Por tanto, construyamos monumentos 'sin uso' o 'vivos', nos enfrentamos al problema de diseñar miles de torres, tumbas, placas, fuentes, arboledas, estelas, estatuas, mausoleos y túmulos. ¿Qué podemos hacer para construirlos mejor que los de la última guerra?" (5)

Andrew Shanken ha esbozado dos razones que pueden explicar el cambio de actitud frente a la conmemoración de las dos guerras mundiales. La primera tiene que ver con el papel de los medios de comunicación en la difusión de imágenes, como la que dio origen al monumento de Iwo Jima, (Fig. 3) mucho más efectivas que los tradicionales elementos conmemorativos:

"La guerra moderna alteró la naturaleza de la conmemoración en un momento en el que la iconografía tradicional estaba asediada, situación demostrada por el monumento de Iwo Jima [...] Su éxito se debió a que en lugar de surgir de una experiencia bélica imaginada o alegórica, procedía direc-

would necessarily have to enrich their formal vocabulary to deal with these new situations: "Calling a bridge a memorial does not make it one. Only that part of a useful structure which is set apart for the dedicatory plaque, statue, hall, fountain, terrace, or the like may be said to serve a memorial function. And that part becomes itself a 'useless' memorial. So whether we build 'useless' or 'living' memorials, we are faced with the problem of designing thousands of towers, tombs, tablets, fountains, groves, boulders, statues, mausoleums, and mounds. What can we do to make these better than the memorials of the last war?" (5)

Andrew Shanken has outlined two reasons which may explain the change of attitude towards commemoration between the two world wars. The first has to do with the role of the media in the dissemination of images, such as that which gave rise to the Iwo Jima memorial, (Fig. 3) much more effective than traditional commemorative objects: "Modern war altered the nature of memorialization at a moment when traditional iconography was under siege, a situation demonstrated by the Iwo Jima Memorial. [...] Its success made sense because rather than emerging from an imagined or allegorical war experience, it came out of the media itself. [...] Iwo Jima aside, the iconic memorial no longer represented the abstract, formerly its domain, because the media made war less abstract". (6) 
tamente de los medios [...] Aparte de Iwo Jima, el memorial icónico ya no representaba lo abstracto, su anterior dominio, porque los medios hicieron la guerra menos abstracta". (6)

La segunda, ligada a la anterior, explicaría cómo la verdadera naturaleza de la guerra quedaría al descubierto gracias a dichos medios, y con ella acciones de ambos bandos difíciles de justificar: "Las dos guerras mundiales fueron nuevos tipos de guerra, luchadas por diferentes razones y a diferente escala que las anteriores. Llegaron con nuevas relaciones con los medios y en un momento en que las convenciones artísticas y arquitectónicas estaban siendo seriamente revisadas. Más aún, el Holocausto y la bomba atómica, ésta como arma y a la vez icono de la Guerra Fría, complicaron aún más la conmemoración”. (7)

Desde esta óptica, resulta fácil entender la suerte desigual que sufrieron dos proyectos de monumentos contemporáneos, ambos diseñados por arquitectos modernos: por un lado el Cambridge Honor Roll, desechado por su carácter exclusivamente conmemorativo, y por otro el Gateway Arch de St. Louis, que paradójicamente empezó siendo un living memorial y del que acabó construyéndose únicamente el elemento sin función práctica. $\mathrm{La}$ elección de estos dos casos de entre un amplio repertorio de posibilidades se debe a que, a pesar de enmarcarse ambos en el contexto de la segunda posguerra norteamericana, utilizar ambos el lenguaje y la tecnología mo-
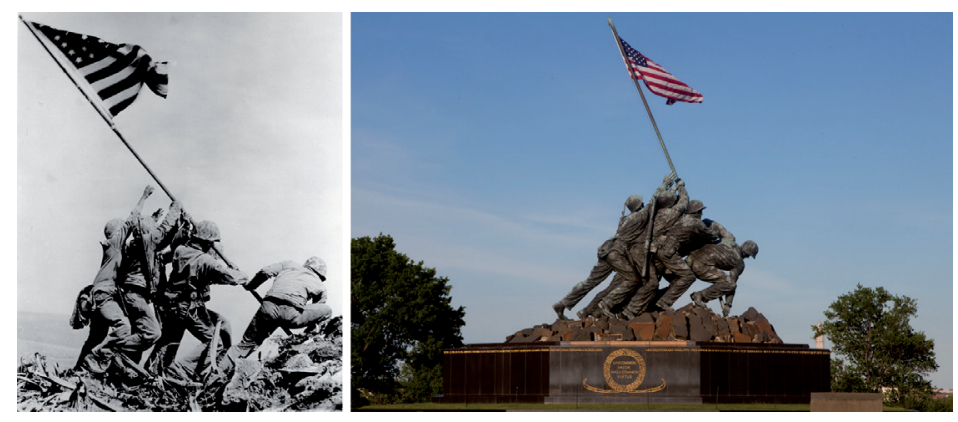

Fig. 3. Fotografía de soldados izando la bandera norteamericana tras la batalla de Iwo Jima, de Joe Rosenthal y Marine Corps War Memorial, situado junto al Cementerio de Arlington.

The second, linked to the one above, would explain how the true nature of the war got exposed by the media, and along with it some actions from both sides difficult to justify: "Both world wars were new kinds of wars, fought for different reasons and on a different scale than earlier wars. They came with new relations to the media at a moment when artistic and architectural conventions were undergoing serious revision. Moreover, the Holocaust and the atomic bomb, the latter as both a weapon and an icon of the Cold War, further complicated memorialization". (7)

From this perspective, it is easy to understand the unequal fate of two projects for contemporary monuments, both designed by modern architects: on the one hand the Cambridge Honor Roll, rejected for its exclusively commemorative character, and on the other the Gateway Arch in St Louis, which paradoxically was initially designed as a 'living memorial' but the only element finally built was the one without practical function. The choice of these two cases from a wide range of possibilities may be explained by the fact that, although both projects were framed in the American post-Second World War context, both made use of modern language and technology, and were repeatedly cited in the theoretical debate of the time, they were opposed in scale, initial program of requirements, and above all, nature of the event commemorated. 
derna, y citarse recurrentemente en el debate teórico de la época, son contrapuestos entre sí en cuanto a escala, programa inicial de necesidades, y sobre todo, naturaleza del acontecimiento conmemorado.

El Cambridge Honor Roll (un cuadro de honor, es decir, una inscripción de reconocimiento) fue diseñado por Marcel Breuer y Lawrence Anderson a propuesta de los decanos de las escuelas de arquitectura de Harvard, Joseph Hudnut, y MIT, William Wurster. Como en tantos otros casos, se organizó un comité asesor para su construcción que estaba formado por los propios decanos, veteranos y miembros del ejército, familiares de los doce primeros soldados de Cambridge caídos durante la guerra y representantes municipales. El monumento debía ser inaugurado el 4 de julio de 1945. Los arquitectos aceptaron el reto de diseñar un objeto sin uso que conceptualmente era equivalente a tantas otras placas conmemorativas, y optaron por convertir un elemento tradicionalmente plano y sólido en algo tridimensional y transparente, organizado de manera que la lectura del texto obligara al movimiento del espectador. En este último aspecto, sí se puede decir que el proyecto incorporaba una cierta dimensión urbana en línea con el living memorial, al proveer un espacio peatonal para el encuentro de ciudadanos. (Fig. 4)

El diseño de Breuer y Anderson (Fig. 5) consistía en una plataforma cuadrada, delimitada por un banco corrido que incorporaba iluminación indirecta, y que era atravesada en su eje por la vía peatonal principal del parque público de Cambridge. Rompiendo el estatismo de esta organización, se disponían de forma aparentemente aleatoria unos paneles de vidrio sin pulir, de siete pies de altura, empotrados directamente contra el terreno, que tendrían grabados al nivel de la vista los nombres de los soldados locales caídos en combate. Se fijó un coste máximo de proyecto y ejecución de 25.000 dólares, pero todas las ofertas recibidas en junio de 1945 superaban ampliamente esa cantidad, lo que obligó a reconsiderar el diseño y a retrasar la ejecución. Finalmente los arquitectos solicitaron un incremento de presupuesto hasta 31.500 dólares que el gerente municipal no llegaría a aceptar de forma oficial.

The Cambridge Honor Roll (i.e. an enrollment of recognition) was designed by Marcel Breuer and Lawrence Anderson at the proposal of the Deans of Harvard and MIT design schools, Joseph Hudnut and William Wurster. As in many other cases, an Advisory Committee was created and composed by the Deans themselves, veterans and military members, families of the first twelve Cambridge soldiers killed during the war and municipal representatives. The monument was to be inaugurated on July 4, 1945. The architects faced the challenge of designing an object without function, conceptually equivalent to many other plaques, and decided to transform a traditionally flat and solid element into a three-dimensional and transparent object, arranged in such a way that the reading of the text would force the movement of the viewer. By providing a pedestrian space for the meeting of citizens, it can be stated that the project incorporated some urban dimension related to the 'living memorial'. (Fig. 4)

Breuer and Anderson's design (Fig. 5) consisted of a square platform, enclosed by a continuous bench that incorporated indirect lighting, and crossed on its axis by the main pedestrian path of the Cambridge Common. Breaking the stillness of this organization, a number of seven-foot-high panels of unpolished glass were arranged in a seemingly random way, embedded directly into the ground, which would have recorded at the sight level the names of local soldiers killed in combat. A maximum cost of 25.000 dollars was established for the project and its execution, but all bids received in June 1945 widely surpassed that amount, which forced the architects to rethink the design and delayed the 
Durante ese proceso, y a pesar de distinguirse claramente de los memoriales de la Primera Guerra Mundial, el diseño de Breuer y Anderson no se libró de críticas por la ausencia de una función práctica. El periódico local Cambridge Chronicle Sun dedicó dos artículos al tema, y aunque no tomaba partido explícitamente ni a favor ni en contra, ponía de relieve las dudas de algunos veteranos que habrían preferido otra forma de conmemorar la guerra. Y en la práctica, la controversia, disfrazada de desviación presupuestaria, provocó que el monumento no se construyera. "El Comité [...] actuó con honestidad al aprobar lo que le parecía en ese momento la forma más deseable de honrar a nuestros excombatientes de Cambridge. Sin embargo, desde entonces los propios soldados han vuelto a Cambridge, y algunos de ellos con los que hemos hablado dijeron que no les preocupaba especialmente ver sus nombres en un cuadro de honor, sino que preferirían que la ciudad creara un Memorial de Guerra que fuera útil a toda la población". (8)

“Es el cuadro de honor de vidrio de 31.500 dólares diseñado para el parque de Cambridge la mejor solución, o debería emplearse el dinero necesario

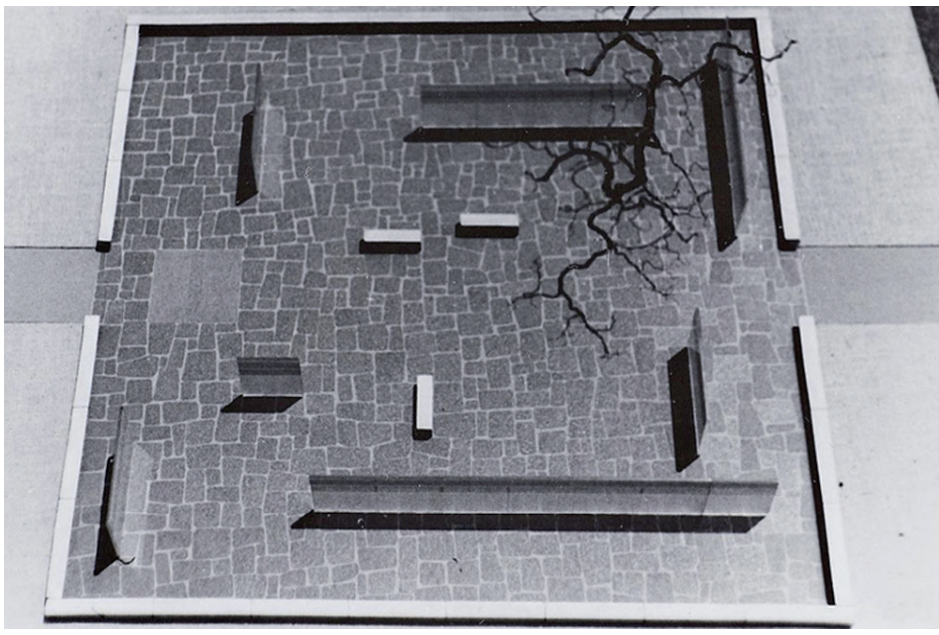

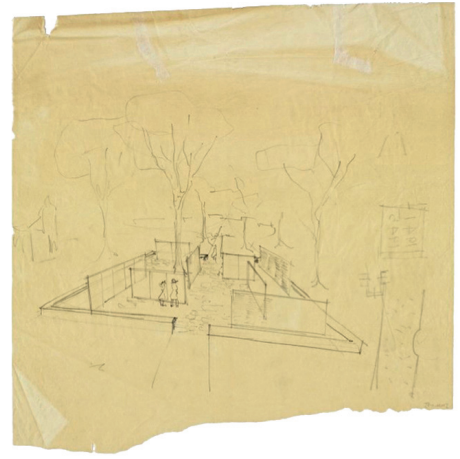

Fig. 5. Maqueta y boceto del diseño de Breuer y Anderson para el Cambridge Honor Roll.

beginning of the construction. Finally, they requested a budget increase to 31.500 dollars that the city manager would not accept officially.

During this process, despite being clearly different from First World War memorials, Breuer and Anderson's design did not escape criticism for the lack of a practical function. The local newspaper Cambridge Chronicle Sun devoted two articles to the subject, and although it did not explicitly take sides for or against, they articulated the doubts of some veterans who would have preferred another way of commemorating the war. And in practical terms, this controversy, disguised as a budgetary slippage, caused the monument never to be built. "This committee [...] conducted its deliberations on a high plane and acted sincerely in approving what seemed to them at the time the most desirable way of honoring our Cambridge servicemen and women. However, since then, the servicemen and women themselves have returned to Cambridge, and some of them, with whom we have talked have said that they do not care particularly about seeing their names on an honor roll, but would rather see the city establish a War Memorial that would be useful to all people of the city". (8) "Is the 31.500 dollars glass honor roll now planned for Cambridge Common the best answer, or should the money appropriated for this purpose be applied toward some other form of memorial like an indoor swimming pool, an athletic stadium, or a memorial building to house all the veterans' posts?" (9) 
para este propósito en alguna otra forma de memorial como una piscina cubierta, un estadio de atletismo o un edificio conmemorativo que aloje los puestos de todos los veteranos?" (9)

Mejor fortuna corrió la propuesta de Eero Saarinen, ganadora del concurso para el diseño del Jefferson National Expansion Memorial de St Louis, conocido habitualmente como el Gateway Arch, que, en lugar de un capítulo bélico, conmemora la compra de Louisiana a Francia y el inicio de la expedición de Lewis y Clark, dos acontecimientos auspiciados por Thomas Jefferson que se produjeron en la ciudad. El primero de ellos supuso la incorporación del territorio que hoy ocupan quince estados norteamericanos, y sobre todo dio al país el control sobre el tráfico fluvial en la cuenca del Mississippi. El segundo tenía entre sus objetivos oficiales el conocimiento de la geografía y las especies naturales del Oeste, pero en la práctica supuso el inició de su proceso de colonización. En cualquier caso, ambos son eventos fundamentales para la conformación de Estados Unidos en el imaginario colectivo. La construcción del monumento había sido promovida desde antes de la Segunda Guerra Mundial por organizaciones cívicas que luchaban por sacar a la ciudad del declive que sufría tras el periodo de esplendor en el que acogió la Olimpiada y la Feria Mundial de 1904, que conmemoraban precisamente el centenario de la compra de Louisiana.

Tras la interrupción de la guerra, se convocó en 1947 un concurso muy bien dotado económicamente cuyas bases pedían "dejar volar la imaginación, dejando el análisis de lo que realmente se puede hacer para un momento menos exuberante". (10) A la primera fase se presentaron 172 propuestas, de las que el jurado seleccionó cinco finalistas para una segunda. Se modificaron entonces las bases, eliminando las partes asimilables a un living memorial y potenciando en cambio el foco monumental, descrito como "un elemento asombroso, para ser visto no sólo desde la distancia en el paisaje, sino también como una estructura notable que sea recordada y comentada como uno de los monumentos más sobresalientes del país". (11)

Eero Saarinen's winning proposal for the competition to design the Jefferson National Expansion Memorial in St. Louis, commonly known as the Gateway Arch, had more luck. Instead of a military event, it commemorated the Louisiana Purchase from France and the beginning of Lewis and Clark's expedition, two events sponsored by Thomas Jefferson that occurred in the city. The first one involved the acquisition of the territory now occupied by fifteen states, and gave the country control over the river traffic on the Mississippi basin. The second one had among its official objectives the knowledge of the geography and natural species of the West, but in practical terms marked the beginning of its process of colonization. In any case, both events are essential for the formation of the United States in the collective imagination. The construction of the monument had been promoted long before Second World War by civic organizations that struggled to get the city out of the decline suffered after the period of splendor in which it hosted the 1904 Olympic Games and World's Fair, commemorating precisely the centennial of the Louisiana Purchase.

After the interruption caused by the war, a very well-funded competition was announced in 1947 whose specifications asked to "give their imaginations free rein, leaving the examination of what can really be done to a less exuberant moment". (10) 172 entries were submitted to the first stage of the competition, from which five finalists were selected to enter a second one. The requirements were then modified, removing the elements related to a 'living memorial' and strengthening instead the 
Así, en la primera fase Saarinen planteaba la inclusión en el conjunto de la Agencia de Naciones Unidas para la Alimentación y la Agricultura: "Debería ser concebida como una fuerza impulsora de la ciencia agrícola en el futuro. De ella fluiría información y exposiciones a todas las partes del mundo [...] La primera unidad de ese edificio contendría la mayor parte del espacio administrativo así como salas de conferencias, grandes áreas para mostrar exposiciones y lugares para encuentros y convenciones". (12) Sin embargo, estos equipamientos desaparecieron en la segunda fase, reduciendo el proyecto a un imponente arco parabólico de acero inoxidable, de 630 pies de luz entre apoyos y 590 pies de altura.

Su proyecto contrastaba con la timidez (en palabras de Architectural Forum) del resto de finalistas, y el jurado no tuvo dudas sobre la concesión del primer premio, otorgado el 17 de febrero de 1948. (Fig. 6) De hecho, el informe final del jurado destaca el hecho de que "el proyecto premiado fue elegido por unanimidad en la primera votación secreta del jurado". (13)

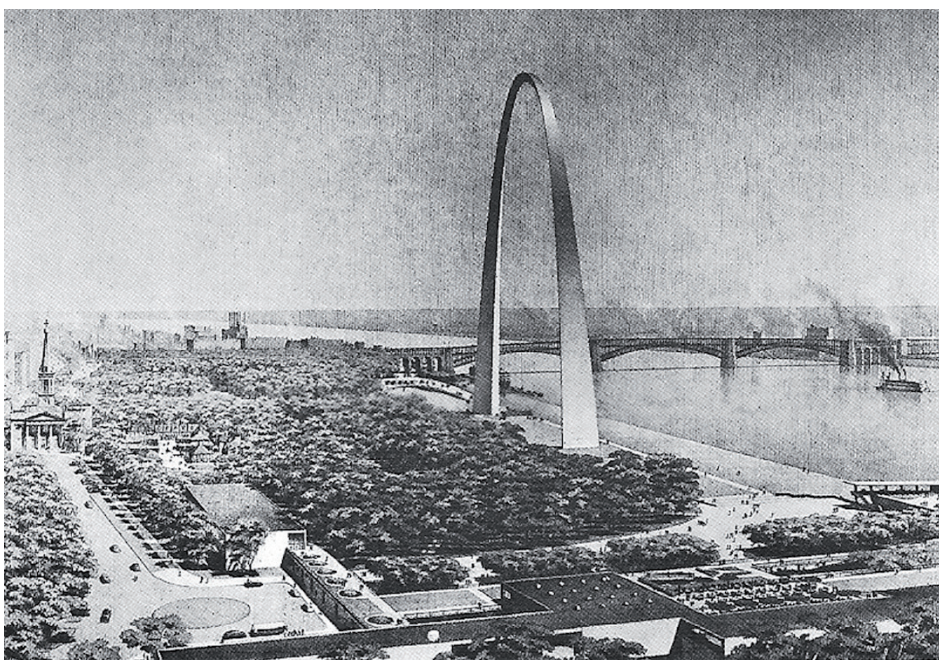

Fig. 6. Propuestas premiadas en la segunda fase del concurso para el Jefferson Memorial. Izquierda, primer premio de Saarinen, Henderson Barr, Kiley, Girard y Swan. Arriba a la derecha, segundo premio de Phillips, Eng y Foster. Abajo, tercer premio de Breger Hornbostel, Lewis, Kline y Tunnard.
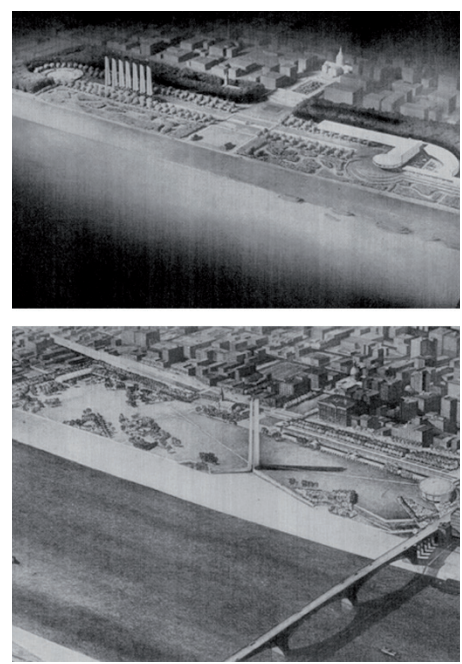

monumental focus, described as a "striking element, not only to be seen from a distance in the landscape but also as a notable structure to be remembered and commented on as one of the conspicuous monuments of the country". (11)

Thus, in the first stage Saarinen proposed the establishment of the United Nations Agency for Food and Agriculture as part of the complex: "This should be envisioned as a future directing force of the world's agrarian science. From it would flow information displays and exhibitions to all parts of the world. [...] The first unit of such a building would contain the major part of the administrative space as well as lecture halls, large areas for the display of exhibitions and places for meetings and conventions". (12) However, these facilities disappeared in the second stage, reducing the project to a stunning stainless steel parabolic arch, 630-foot span between supports and 590 feet high. This project contrasted with the shyness (in the words of Architectural Forum) of the other finalists, and the jury had no doubts about the award of the first prize, issued February 17, 1948. (Fig. 6) In fact, the jury's final report highlights the fact that "the winning award was made by a unanimous vote on the Jury's initial secret ballot." (13)

Saarinen's design undoubtedly responded to a classical scheme, respected the axis of the old courthouse, and was even drafted for the competition using the washing technique from the Beaux-Arts tradition. Moreover, it generated a brief 
El diseño de Saarinen respondía indudablemente a un esquema clásico, respetaba el eje del antiguo Palacio de Justicia, e incluso se dibujó para el concurso según la técnica de lavado de la tradición Beaux-Arts. Más aún, generó una breve pero intensa polémica por su semejanza al arco fascista diseñado por Adalberto Libera para la Exposición Universal de Roma de 1942. Sin embargo, era radicalmente moderno en cuanto a su audacia estructural y al material utilizado, y estas cualidades garantizaron el empeño en construirlo, a pesar de que las dificultades económicas retrasaron el inicio de las obras hasta 1962. El arco se coronó en octubre de 1965, (Fig. 7) convirtiéndose entonces en el monumento más alto de América, por encima del Monumento a Washington y de la Estatua de la Libertad. La inauguración se produjo en mayo de 1968, y la operación completa costó unos cuarenta millones de dólares. Hoy día sigue siendo la imagen de St. Louis y la pertinencia y necesidad de su construcción nunca han sido cuestionadas.

Antes al contrario, que el pueblo americano acogió el arco como una creación propia y original queda bien reflejado en las palabras de William Gass: "El monumento europeo está hecho de Tiempo transformado en piedra e inmovilidad [...] Aquí, el monumento es Espacio convertido en vida cotidiana y puesto en movimiento como una carretera [...] El arco de Saarinen es una expresión perfecta de nuestra posición. Aspira. Se abre. Mira al Oeste, pero no tiene cara. Como el puente del Golden Gate [...] se eleva y se extiende. Miramos a través de él, quizá al Palacio de Justicia, pero su significado es moderno; está hecho de acero inoxidable, no de piedras antiguas. Y necesitamos que sea inoxidable, trascendental, ¿no es cierto?” (14) Y que su valor simbólico superaba con creces la inversión económica realizada es el argumento con el que Peter Blake respaldó la construcción del arco: "Gracias a la construcción del arco, se han invertido cientos de millones de dólares en nuevos edificios alrededor del parque que de otra forma no se habrían gastado; y millones de personas han venido a visitar el centro de St. Louis que de otra forma no habrían venido. Más aun, se ha dado a la ciudad una nueva identidad simbólica [...] Estoy seguro de que hubo cantidad de gente práctica [...]; pero nadie los escuchó, y nadie recuerda sus nombres. Ni tienen por qué". (15)

but intense controversy for its resemblance to the fascist arch designed by Adalberto Libera for the Universal Exhibition of Rome, 1942. However, it was radically modern for its structural audacity and the selected material, and these qualities ensured the commitment to build it, despite the economic difficulties which delayed the beginning of construction until 1962. The arch was crowned in October 1965, (Fig. 7) becoming the tallest monument in America at the time, surpassing the Washington Monument and the Statue of Liberty. The inauguration took place in May 1968, and the entire operation cost about forty million dollars. Today it is still the icon of St. Louis and the relevance and necessity of its construction have never been questioned.

Just to the contrary, the American people welcomed the arch as their own original creation as is well reflected in the words of William Gass: "The European monument is made of Time turned to stone and stood still. [...] Here, the monument is Space turned into daily life and set moving like a road. [...] Saarinen's arch is a perfect expression of our position. It aspires. It opens out. It looks West, but it has no face. Like the Golden Gate Bridge [...] it soars and spans. We look through it at the Courthouse, perhaps, but its meaning is modern; it is built of stainless steel, not of old stones. And we need to be stainless, transcendental, don't we?" (14) And the fact that its symbolic value far exceeded the economic investment is the reason why Peter Blake supported the construction of the arch: "Because his arch was built, hundreds of millions of dollars have been 


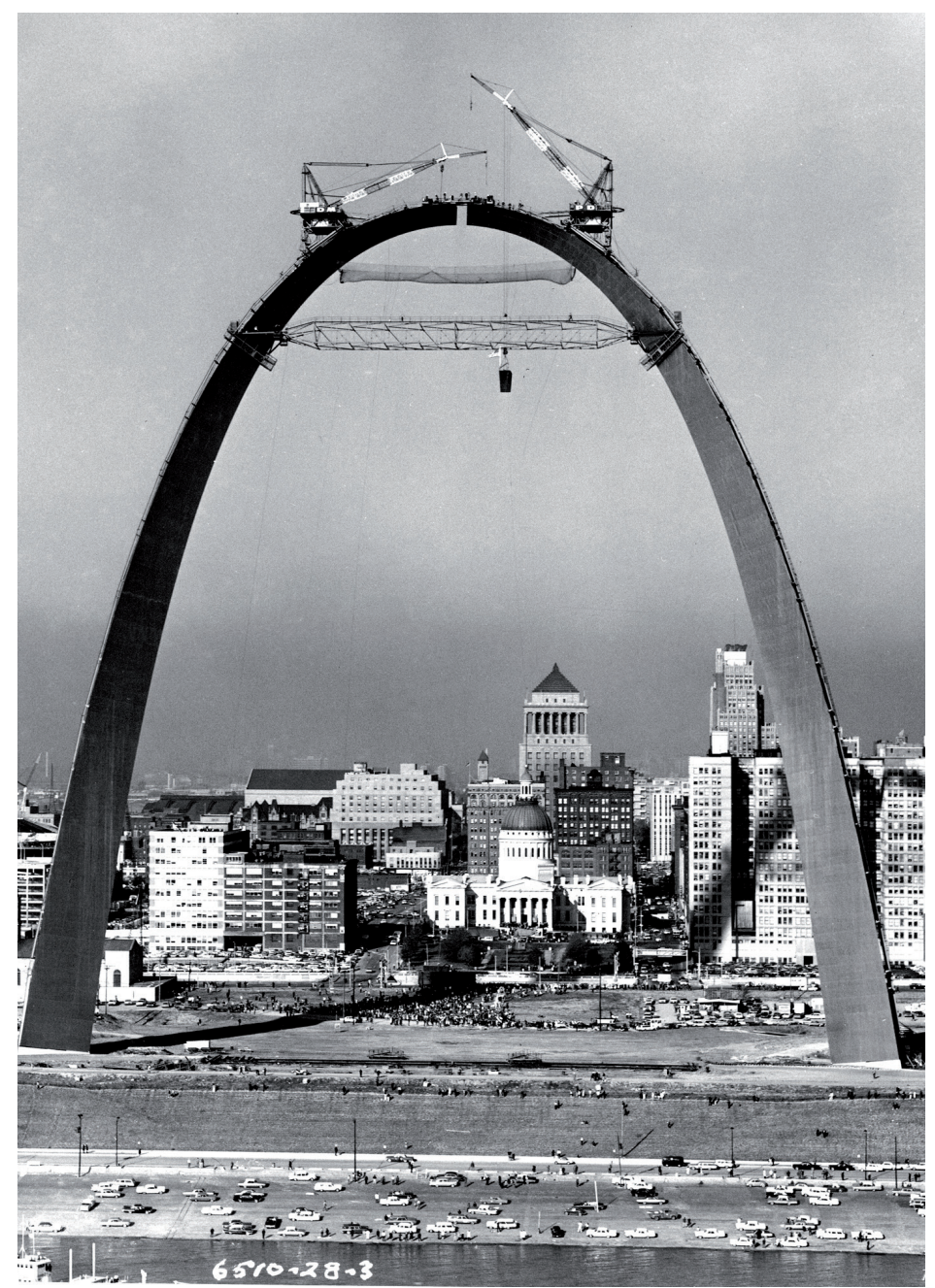

Fig. 7. Colocación de la última dovela del arco.

spent on new buildings all around the Gateway's park that would have not been spent otherwise; and millions of people have come to visit Downtown St. Louis, who would not have come otherwise. Moreover, the city has been given a new symbolic identity. [...] I am sure there were plenty of practical people; [...] but no one listened to them, and no one remember their names. Nor should they". (15)

Joseph Hudnut stated "no picture, not even a thousand pictures, can show us war". (16) But perhaps it would have been more accurate to say the opposite, that the proliferation of images finally showed the true face of war, in which heroism lives together with misery and meaninglessness. The traditional monument could no longer ignore this new awareness and the 'living memorial' then became a way to put the focus on the positive lessons of war rather than its disastrous consequences. In these circumstances, the city of Cambridge did not see fit to invest 31.500 dollars in a project that just evoked the memory of lost lives. In contrast, the milestones that shaped the collective identity of the United States were shown without reference to controversy and Saarinen knew how to give them a contemporary expression. Thus, despite its cost and the lack of practical utility, the project was sustained for decades. Moreover, the investment was considered fully redeemed by benefits whose nature was not only material, but fundamentally spiritual: the construction of a common history, of a collective identity. 
Joseph Hudnut afirmaba, "ninguna imagen, ni mil de ellas, puede mostrarnos la guerra”. (16) Pero quizá habría sido más exacto decir lo contrario, que la proliferación de imágenes mostró finalmente la auténtica cara de la guerra, en la que el heroísmo convive con la miseria y el sinsentido. El monumento tradicional ya no pudo obviar esta nueva conciencia y el living memorial se convirtió entonces en una forma de poner el foco en las enseñanzas positivas de la guerra por encima de sus desastrosas consecuencias. En estas circunstancias, la ciudad de Cambridge no consideró oportuno invertir 31.500 dólares en un proyecto que simplemente aportaba el recuerdo de unas vidas perdidas. Por contra, los hitos que forjaron la identidad colectiva de los Estados Unidos se mostraban ajenos a toda polémica y Saarinen supo darles una expresión contemporánea. De esta manera, a pesar del coste y la falta de utilidad práctica, el proyecto se mantuvo vivo durante décadas. Más aún, el dinero invertido se consideró cumplidamente amortizado por beneficios de carácter no sólo material, sino fundamentalmente espiritual: la construcción de una historia común, de una identidad colectiva.

\section{NOTAS}

1. CANDLER, Martha. 'The Community House as a War Memorial'. American Architect. vol. 66, n. 2277, (Agosto de 1919). 207 p.

2. SWARTWOUT, Egerton. 'Memorial Buildings'. Architectural Forum. vol. 45, (Diciembre de 1926). 330 p.

3. REID, Kenneth. 'Memorials? Yes - But No Monuments!'. Pencil Points. vol. 25, (1944). 35 p.

4. HOWE, George. 'Monuments, Memorials and Modern Design - an Exchange of Letters'. Magazine of Art. vol. 37, (Octubre de 1944). 204 p.

5. JOHNSON, Philip. 'War Memorials. What Aesthetic Price Glory?'. Art News. vol. 44, (Septiembre de 1945$) .10$ p. 6. SHANKEN, Andrew. 'Planning Memory: Living Memorials in the United States during World War II'. The Art Bulletin. vol. 84, (Marzo de 2002). 134 p.

7. Ibídem. $144 \mathrm{p}$.

8. 'That War Memorial'. Cambridge Chronicle Sun, 5 de Mayo de 1946. 12 p.

9. 'What Will Cambridge Do About Memorial? Is An Honor Roll the Best Answer? Veterans Are Invited to Make their Views Known'. Cambridge Chronicle Sun, 5 de Septiembre de 1946. 1p.

10. 'Jefferson National Expansion Memorial Competition'. Architectural Forum. vol. 88, (Marzo de 1948). 14 p.

11. Ibídem. 17 p.

12. Extracto de la memoria de la primera fase del proyecto.

13. 'Final Report of the Jury of Award'. Transcrito en 'Competition: Jefferson National Expansion Memorial'. Progressive Architecture. vol. 27, (Mayo de 1948). pp. 52-53.

14. GASS, William. 'Monumentality/Mentality'. Oppositions. vol. 25, (Otoño de 1982). 142 p.

15. BLAKE, Peter. 'Monument to the Dream'. Interior Design, Enero de 1991. 139 p.

16. HUDNUT, Joseph. 'The Monument does not Remember'. The Atlantic Monthly. n. 176, (Septiembre de 1945). 57 p.

\section{NOTES}

1. CANDLER, Martha.'The Community House as a War Memorial'. American Architect. August, 1919, vol. 66, n. 2277,207 p.

2. SWARTWOUT, Egerton. 'Memorial Buildings'. Architectural Forum. December 1926, vol. 45, 330 p.

3. REID, Kenneth. 'Memorials? Yes - But No Monuments!'. Pencil Points. 1944, vol. 25, 35 p.

4. HOWE, George. 'Monuments, Memorials and Modern Design - an Exchange of Letters'. Magazine of Art.

October, 1944, vol. 37, 204 p.

5. JOHNSON, Philip. 'War Memorials. What Aesthetic Price Glory?'. Art News. September 1945, vol. 44, 10 p.

6. SHANKEN, Andrew: 'Planning Memory: Living Memorials in the United States during World War II'. The Art Bulletin. March, 2002, vol. 84, 134 p.

7. Ibídem. 144 p.

8. 'That War Memorial'. Cambridge Chronicle Sun. May 5, 1946. 12 p.

9. 'What Will Cambridge Do About Memorial? Is An Honor Roll the Best Answer? Veterans Are Invited to Make their Views Known'. Cambridge Chronicle Sun. September 5, 1946. 1 p.

10. 'Jefferson National Expansion Memorial Competition'. Architectural Forum. vol. 88, (March 1948 ). 14 p.

11. Ibídem. 17 p.

12. Excerpt from the memory of the first stage proposal.

13. 'Final Report of the Jury of Award'. Included in 'Competition: Jefferson National Expansion Memorial', Progressive Architecture. vol. 27, (May 1948). pp. 52-53.

14. GASS, William. 'Monumentality/Mentality'. Oppositions. vol. 25 (Autum 1982). 42 p.

15. BLAKE, Peter. 'Monument to the Dream'. Interior Design, January 1991. 139 p.

16. HUDNUT, Joseph. 'The Monument does not Remember'. The Atlantic Monthly. n. 176, (September 1945). 57 p. 